2L LINGUACULTURE 2, 2019

\title{
"THE LANGUAGE OF JOY": \\ C.S. LEWIS'S LEGACY AS A CHRISTIAN COMMUNICATOR TO CONTEMPORARY CULTURE
}

\author{
Monika HILDER \\ Trinity Western University, Langley BC, Canada
}

\begin{abstract}
In this paper, I explore C.S. Lewis's legacy as apologist and artist of the Christian faith and claim that Lewis, like his mentor George MacDonald before him and his friend Dorothy L. Sayers, successfully engaged contemporary culture by speaking the wildly attractive language of Joy. Both as rational defender of the Christian faith and as an imaginative storyteller, Lewis conveyed this quality of Heavenly Joy that invites and inspires the hearts and minds of readers to rethink, reconsider, and perhaps for the first time in their lives experience Beauty and Love-to truly encounter what proves to be the lasting Hope of the world. In this I point to three characteristics that resulted in Lewis's success as a Christian apologist: 1) the recovery of earlier ideas; 2) the use of everyday language; and 3) the habit of humility. Then I speak of how in his imaginative fiction this language of Joy sees Beauty and both testify to Love-and it is these literary experiences that move the hearts and minds of readers.
\end{abstract}

Keywords: Apologist, Imaginative Storyteller, Culture, Joy, Beauty, Love

\section{Introduction}

"Joy is the serious business of Heaven." So C.S. Lewis wrote in Letters to Malcolm (p. 93), his last book, which was published in 1964, a few months after his death. And Joy, Joy with a capital "J" Joy, is easily thought of as the defining characteristic of this giant of a man, for giant in faith and in works C.S. Lewis was.

Lewis has been described as a man of laughter: a "jovial man" who "possessed an angelic mirth" (Lindvall, p. 5), as one who once said, "no sound 
delights me more than male laughter" (W.H. Lewis, p. 14). He loved jokes. His gentle smiles are most endearing. One of my own favourite Lewis smiles is in the photograph of him ${ }^{1}$ in which overtop of his manly suit, white shirt and tie, he's wearing what looks to me like an interesting housecoat, its collar and edgestitching almost suggestive of something "feminine." He looks jovial, even impish. He is holding his pipe with a casual grasp, and the beaming smile that flows from his entire face suggests mirth and mischief and mystery all at once. As if he knows some spectacular secret and is quite sure that we will discover what it is.

His whimsical smile seems to say, "Don't you know? Oh, but you do know! Or you soon shall know why I'm smiling! And once you know I'll bet it'll set you smiling too! I very much hope so! Mind you, it isn't really a secret. But the thing is so big that it's often missed. Do you want me to tell you what it is? Well, I will then! My smile comes from the Great Wonderful Laughter at the core of this universe! It's a Laughter so rich and deep and wide that all the world cannot contain it! This Laughter set the stars singing and the planets dancing, don't you know? This Laughter keeps every atom in place. And wonders of wonders, this Laughter, so strong, and yet so kind, reached down into the dark, proud, small heart of a quite highly educated but very arrogant and rather lonely man, a silly Oxford professor-me, of course! - a man who sought the deep happiness which he did not rationally believe he could find. In fact, he did his best to run and hide from the very Source of True Happiness until one day, thank Heaven! he was at last outrun. It was rather hard on him to be found out, to be dead wrong. A blow to his pride. But then, quite suddenly, and for the rest of his days, he became glad. This divine Laughter rescued him-that man that I was, me! - this divine Laughter rescued me from sin, death, and everlasting despair!

"Oh, I tell you, this Laughter has given me a Joy that has nothing to do with happiness as this world counts happiness. For pleasant thoughts and feelings that at best coincide with mere happenstance, circumstances which seem to satisfy our hopes and aspirations, are but a poor imitation of the Joy, deep uplifting Joy of which I'm talking of. How shall I explain it? How can I show you what I mean?”

That's my attempt at trying to sound like C.S. Lewis, and show what his writings have been saying to me.

In his autobiography Surprised by Joy, Lewis describes what he meant by Joy, which he regarded as "the central story of [his] life" (p. 20). This Joy, he wrote, is "a sensation of ... a desire," something like what Milton called the "'enormous bliss' of Eden" (p. 19). It is a longing that suddenly arises and just as soon disappears, but Lewis asserts that this desire, therefore unsatisfied, "is more desirable than any other satisfaction” (p. 20). Of his first experience of Joy

\footnotetext{
${ }^{1}$ Photo of C.S. Lewis by Norman Parkinson, Vogue, November 1951.
} 
as a young child when his brother had taken his toy garden into their nursery, Lewis said, "It had taken only a moment of time; and in a certain sense everything else that had ever happened to me was insignificant in comparison" (p. 19). He explains,

I call it Joy, which is here a technical term and must be sharply distinguished both from Happiness and from Pleasure. Joy (in my sense) has indeed one characteristic, and one only, in common with them; the fact that anyone who has experienced it will want it again. Apart from that, and considered only in its quality, it might almost equally well be called a particular kind of unhappiness or grief. But then it is the kind we want. I doubt whether anyone who has tasted it would ever, if both were in his power, exchange it for all the pleasures in the world. But then Joy is never in our power and pleasure often is. (p. 20)

Lewis spent the rest of his life explaining and showing what this Joy meant. As Christopher W. Mitchell underscored, Lewis's lifelong "evangelistic impulse” informed all of his writings because he "longed above all else for the unseen things of which this life offers only shadows, for that weight of glory which the Lord Christ won for the human race" (Bearing the Weight”, p. 3, 13-14). Moreover, Lewis did not compromise on the value of the individual: the value of "Nations, cultures, arts, civilization," as he said, is as small "as the life of a gnat," a tiny insect, in contrast with the value of one eternal human soul ("The Weight of Glory", p. 15). "Nature," Lewis declared, "is mortal; we shall outlive her. When all the suns and nebulae have passed away, each one of you shall still be alive" (p. 13). Thus Mitchell concluded, "knowing the extraordinary nature of every human person, Lewis longed for and labored for their glory as well" ("Bearing the Weight", p. 14).

And Lewis has indeed proven to be both the foremost twentieth-century apologist and artist of the Christian faith—a legacy that is still growing. Lewis was the professor's professor, the artist's artist, and everyman's theologian. The contemporary critic William Empson described him as "the best-read man of his generation, one who read everything and remembered everything he read" (qtd. in Como, p. 35). Lewis was a most astounding Christian communicator to contemporary culture. When Britain fought its darkest hour under the threat of Nazi invasion during World War II, he was the voice on BBC radio that encouraged his people in the Christian faith, and these talks became the basis of his theological book Mere Christianity. His children's fantasy adventures into Narnia have captured the hearts of millions, young and old. His works of literary scholarship remain vital in academe. Indeed, Lewis was a man of far-reaching talent whose legacy as a Christian communicator to contemporary culture continues to speak to us. 
People are sometimes embarrassed to quote him so often, yet we continue to do so. In fact, there's so much that Lewis thought about and achieved that we are still learning from him as well as from those who influenced him, such as his nineteenth century mentor, Victorian author George MacDonald, and his own friends, including author Dorothy L. Sayers. Just how did Lewis do it? we have cause to wonder. And what does this tell us-that the legacy of Clive Staples Lewis, one of the most brilliant men of the twentieth century, might be caught in one word: Joy?

Joy could well be the serious business of Heaven, we may say in agreement with Lewis, but where does this leave us meanwhile in this life, a world captive to materialism, violence, and existentialist despair? A world in which every person's life is what Lewis called "a via crucis," the Way of Sorrows, the Way of the Cross, in which we find ourselves, as he says, "cursed with labour, hemmed round with necessities, tripped up with frustrations, doomed to perpetual plannings, puzzlings, and anxieties..."

(Letters to Malcolm, p. 92). And a world in which many believe they understand the Christian faith, but probably do not, and in any case want nothing to do with it?

In 1949 Lewis's friend Dorothy Sayers described England as only a nominally Christian country which had little to no understanding of what Christianity actually was. She stated,

It would not perhaps be altogether surprising if, in this nominally Christian country, where the Creeds are daily recited, there were a number of people who knew all about the Christian doctrine and disliked it. It is more startling to discover how ma[n]y people there are who heartily dislike and despise Christianity without having the faintest notion what it is. If you tell them, they cannot believe you. I do not mean that they cannot believe the doctrine; that would be understandable enough since it takes some believing. I mean that they simply cannot believe that anything so interesting, so exciting, and so dramatic can be the orthodox creed of the Church. ("Dogma is the Drama", p. 24)

In other words, if this exciting doctrine is the true Christian faith, what was wrong with how Christians were communicating the message in 1949? Likewise, we might ask, what might be wrong with how Christians are communicating the message today?

In recent times, questions of Christians communicating their faith to contemporary culture have intensified. This is especially so in the face of documentation that more Christians have been persecuted and martyred for their faith in the twentieth century than in all of the previous centuries combined (qtd. 
in Wooding), ${ }^{2}$ and according to a recent (2017) report the "incidents [are] occurring on every continent" (Chiaramonte 2017). And the Western world, which has enjoyed great religious freedom, is often considered to be largely "post-Christian" (cf. Butterfield, p. 47-64). In 2017 Robert C. Trube asked, "Is contemporary Christianity in America on the ropes? Have Christians engaged in culture wars and lost?” In America, and visibly throughout the Western world, as several European sources indicate, we now live in a climate where conservative Christian evangelism itself is sometimes thought of and at times treated as a hate crime (Mohler). The West, arguably, has undergone a moral revolution which Theo Hobson describes as having three marks:

1. What was universally condemned is now celebrated.

2. What was universally celebrated is now condemned.

3. Those who refuse to celebrate are condemned.

(qtd. in Butterfield, p. 51)

Therefore, as Trube asks, "And if this is indeed so [that Christians have lost the culture wars], what might be done to recover and re-engage, if not in culture wars, in an effort to capture the hearts and minds of the rising generation"? ${ }^{3}$

In this paper I claim that members of the Inklings and friends, notably C.S. Lewis but not only Lewis, most successfully communicated the Christian faith. Moreover, he continues to challenge and delight the hearts and minds of millions of readers, young and old. And he did it through speaking the wildly attractive language of Joy. Lewis's response to culture was not "un-Christlike pessimism" (Gilson 2017) but Christ-like joy. Both as a rational defender of the Christian faith and as an imaginative storyteller, Lewis conveyed this quality of Heavenly Joy that invites and inspires readers to rethink, reconsider, and perhaps for the first time in their lives experience Beauty and Love- to truly encounter what proves to be the lasting Hope of the world. This is how Lewis did it.

I begin with a brief sketch of Lewis as the rational defender of the faith. Without his commitment to the dogma-the foundational teachings of the Christian faith-we would not be here today, contemplating his far-reaching achievement. As Sayers famously argued, ridicule of the Christian faith by ignorant atheists, as well as the boredom of bland or nominal-only Christians, all

\footnotetext{
2 “Justin D. Long emphasized the startling fact that more people have died for their faith in the Twentieth Century than in all of the previous centuries combined. "During this century, we have documented cases in excess of 26 million martyrs. From AD 33 to 1900, we have documented 14 million martyrs” (qtd. in Wooding); cf. Morgan Lee.

3 The place of Christian engagement in "the culture wars" is a vast topic that goes well beyond the scope of this paper. Nor am I suggesting that Lewis advocates that Christians "win the culture wars" (there is, in my view, evidence to the contrary). Instead, in this paper I explore his commitment to engaging culture and the reasons for his success.
} 
of whom do not grasp how Jesus turned the world upside down — or right side up-must be challenged with the sharp Truth. Churches are not empty because preachers focus on doctrine, she argued. "The fact is the precise opposite. It is the neglect of dogma that makes for dullness. The Christian faith is the most exciting drama that ever staggered the imagination of man-and the dogma is the drama" ("Greatest Drama”, p. 11). Sayers hammered this point home:

It is the dogma that is the drama-not beautiful phrases, nor comforting sentiments, nor vague aspirations to loving kindness and uplift, nor the promise of something nice after death—but the terrifying assertion that the same God who made the world lived in the world and passed through the grave and gate of death. Show that to the heathen, and they may not believe it; but at least they may realize that here is something that a man might be glad to believe. (“Dogma is the Drama”, pp. 27-28)

C.S. Lewis excelled in clearly explaining Christian dogma—and he did so with enthusiasm, with a joy as robust as his logic. As a professor, Lewis loved few things better than a good, rousing critical argment. He has been described as the "bonny fighter" (Farrer, "Christian Apologist", p. 25) of the Oxford Socratic Club, a club where Christians and non-Christians honestly debated the intellectual claims - “the pros and cons" (Mitchell, "Making Doctrine Dance”, p. 25) - of Christianity. A formidable opponent in debate, Lewis had, it has been said, "combative pleasure" (Coghill, p. 52) in giving "knockdown arguments" (Wain 153). He fought hard to win debates. And he did so out of the tradition of the Christian knight who, as he said himself, "offers the only possible escape from a world divided between wolves who do not understand, and sheep who cannot defend, the things which make life desirable" ("The Necessity of Chivalry”, p. 16). Christians, he believed, must be warriors who defend the weak and the innocent against the violence and deception of evil forces in our world.

Lewis's success as a Christian apologist has at least three characteristics: 1) the recovery of earlier ideas; 2) the use of everyday language; and 3) the habit of humility.

First, Lewis was committed to educating academics and the general public alike on the importance of recovering earlier ideas. As an "intellectual historian," as Dennis Danielson has called him, Lewis drew attention to ideas of the past, not because all the ideas of the past were better than our own, but because we are all influenced by our own time and knowledge of the past can serve to correct the weaker or dangerous ideas in our own time ("Reading of Old Books", pp. 200-7). Most people of the past held one thing in common that many of us have apparently lost or denied: objective moral Truth. In recent times as in Lewis's day, many argue that truth is relative to context. But Lewis held firm to the old idea of objective moral Truth, unchanging Truth, the Tao as he referred to it (Abolition of Man). And in light of this belief, he challenged many 
modern assumptions. For example, Lewis suggested that we "probably ... within certain limits," get the science we want and named the reasons why we wanted evolution ("Funeral of a Great Myth", pp. 82-99). He debated the logic of scientific materialism (“Is Theology Poetry?"). He disputed the Freudian reductionism of human motivation ("Psycho-analysis and Literary Criticism"). He emphasized that modern biblical theologians were not properly skeptical about their own assumptions ("Modern Theology and Biblical Criticism"). He warned against the coming commitment to what we now call transhumanism, which would, if realisable, abolish humanity (Abolition of Man). Likewise, he warned against a totalitarian reshaping of human conscience toward this new transhumanist, technocratic man who has no moral convictions in the old sense of the meaning (Abolition of Man). He forewarned against the tyranny of the few with power in a new world order who would seek to recondition and enforce what the many must believe (pp. 73-74). Thus, Lewis tried to recover our earlier belief in objective moral Truth in order to alert us to the dangers of modern progressivism with all its forms of ideological warfare. Certainly he has been hailed as nothing short of prophetic in diagnosing the ills of our time. Bruce L. Edwards judged that Lewis's "rehabilitative" approach to the past is such that he "will [one day] emerge as the sanest and most innovative of men" (p. 30, 35).

Second, Lewis was committed to translating his knowledge and insights into ordinary language that any average person on the street could understand. As an academic, he had to work at it too, as he first discovered when he gave a talk to a group of British soldiers during World War II. Lewis's challenge to academics is this: if you can't explain a concept in ordinary language so that it's intelligible to less educated people, this means that you really do not understand it yourself ("Before We Can Communicate", pp. 256-7). Please, no academic jargon. Try, therefore, he urged, to translate important ideas for all to graspthis is central to his legacy.

Third, although Lewis has sometimes been portrayed as a boisterous bully, he practised humility. He knew he could always be wrong and said so. For example, he said that if he finds out that he has only been following his own ideas once again that he hopes he would respond along the lines of what Dante in Paradiso (XXVIII) said of "poor Pope Gregory," whereupon arriving in Heaven and finding "that his theory of the hierarchies . . . was quite wrong.... [thought] [i]t was the funniest thing he'd ever heard" ("Christianity and Literature", p. 11). Lewis knew too from experience how hard it is to become a Christian (L3: 1264). He also understood the limits of logical argument to reach people for Christ. ${ }^{4}$ Even as a believer, and especially as an apologist, he wrestled

${ }^{4}$ Lewis spoke of how reading MacDonald's Phantastes "baptize[d] ... [his] imagination" long before he gave intellectual assent to the Christian faith ("Preface", p. 34). He emphasized that in the process of writing imaginative literature the writer might 
with doubt ("Apologist's Evening Prayer), and he agreed with a correspondent, " "Christianity is a terrible thing for a lifelong atheist to have to face" (L3: 1264). His own writings also convicted his conscience: for example, he said, "I was rather frightened myself by the Great Divorce - condemned out of my own mouth" (L2: 790). And he grasped that many of us share in the guilt over the current evils we face, as illustrated in his character Professor Dimble in That Hideous Strength, who admits that many of the ideas that led to a totalitarian takeover had been taught in the universities for years, himself included (pp. 36970). Lewis's humility while defending or explaining the Christian faith through logical argument also seems to be informed by the confident faith of his primary mentor, George MacDonald, who in his children's book The Princess and the Goblin, in the voice of the great-grandmother of the silver moon, underscored the idea that "People must believe what they can, and those who believe more must not be hard on those who believe less" (p. 153). When the child Princess Irene wonders why her friend Curdie disbelieved in the existence of the supernatural grandmother figure, the wise lady replies, "We are all very anxious to be understood, and it is very hard not to be. But there is one thing much more necessary.” When Irene asks what that is, Grandmother replies, "To understand other people" (p. 156).

To understand people is precisely what Lewis sought to do: to understand how people think in one's culture, and, in his words, to "beat them at their own game" ("Christianity and Culture", p. 17). But winning an argument is not the same as winning a friend or a soul for Christ-heart and mind together. And as Alistair McGrath has said, if Lewis had only written argumentatively, it is unlikely that he would be famous today. We remember Lewis especially because of his imaginative fiction, stories that invite readers inside the thrilling dogma of Christian faith. He could tell a really good story. As Austin Farrer has claimed, "[Lewis's] real power was not proof; it was depiction. There lived in his writings a Christian universe that could be both thought and felt" ("In His Image," pp. 384-85). Lewis himself said, "The imaginative man in me is older, more continuously operative, and in that sense more basic than either the religious writer or the critic" (L3: 516-7). He also said he would not care for a planet of "pure intelligence": he needed to have sensual experience, "affection," and some "Nonsense!" (L3: 662-63). Perhaps it is possible to miss the full joyous nature of Lewis's argumentative writings. But in his imaginative fiction Lewis's language of Joy sings off the pages. Joy sees Beauty and both testify to

\footnotetext{
“steal past those watchful dragons” responsible for readers' emotional resistance to Christianity ("Sometimes Fairy Stories May Say Best What's to be Said”, p. 47). Likewise, he wrote, "[a]ny amount of theology can now be smuggled into people's minds under cover of romance without their knowing it” (L2: 262).
} 
Love-these are the experiences that deeply move the hearts and minds of readers.

\section{Joy}

Whether in his fictional worlds or in re-imagining our own, Lewis creates experiences of enormous Joy. While the dark forces bind people in slavery and banish every suggestion of fun and hope, the winning team knows how to party in spacious freedom. While the dark forces operate on the basis of cruel competition and scarcity, the winning team operates on the principles of community and plenitude. All that is not well shall become well. In the midst of the gravest dangers, and especially with the victory won over them, it is obvious that exuberant Joy is the very reason for life.

In the Chronicles of Narnia, there is much feasting and fine fellowship. Food, laughter, dance, and general merry-making seem to be the ultimate purpose of life, and all are invited to join in this great wonderful festivity of divine origins. In The Lion, the Witch and the Wardrobe, the children enjoy a delicious meal with Mr. and Mrs. Beaver before they escape from the coming of the White Witch. Father Christmas arrives, bringing gifts and spreading cheer wherever he goes. When the great battle with the enemy is over, Aslan is the merry host who provides high tea for all. On the next day at the coronation of the four Pevensie children there is "a great feast in Cair Paravel" with "revelry and dancing" where "gold flashed and wine flowed," and the music inside the castle is answered by the "stranger, sweeter, and more piercing" music of the sea people outside (p. 165). In Prince Caspian, Caspian and his friends join in the dance with the fauns (75). In The Voyage of the "Dawn Treader" the travellers are refreshed with a sumptuous meal at Aslan's Table (p. 169). In The Silver Chair, the liberated inhabitants of Bism shout and cheer, "lea[p], tur[n] cartwheels, stan[d] on their heads, pla[y] leap-frog, and le[t] off huge [fire-] crackers” (p. 173). The same joyous mood is seen in the elaborate game of the Great Snow Dance of Fauns and Dryads where a snowball happens to get Jill in the mouth and she does not mind a bit. The music is "wild, intensely sweet, and yet just the least bit eerie too, and full of good magic" (p. 185). And in The Last Battle, when the company arrives in Aslan's country, the true Narnia, their joy is never-ending. All that had been lost is found. The dead are alive. The best of their old life is transfigured. Their true story begins-all their sorrows have been swallowed up in victory. The narrator declares,

... and we can most truly say that they all lived happily ever after. But for them it was only the beginning of the real story. All their life in this world and all their adventures in Narnia had only been the cover and the title page: now at last they 
were beginning Chapter One of the Great Story which no one on earth has read: which goes on for ever: in which every chapter is better than the one before.

And truly, there is no mourning for even the best of their past lives. When Peter and Edmund see England in the eternal Narnia, including Professor Kirk's old house that had been destroyed, Mr. Tumnus explains that they are now seeing "the England within England, the real England.... And in that inner England no good thing is destroyed" (pp. 163-64). In fact, "all the real countries"-or everything that was good in every country - is present in the eternal Narnia (p. 164). The reader grasps that the best of one's home country-the best of Canada, the best of Romania, the very best of Iasi-will rejoice in this celebration that never ends. No matter what sorrows one has undergone, it is clear that the true country, the true Romania, the Romania that always was and will be, is there, in Aslan's country, and here, now, in our hearts, and always. We already feel it and we will see it in glory forever. Ultimately, nothing good is ever lost.

\section{Beauty}

Lewis's language of Joy sees Beauty. With a heart full of Heavenly Joy, he points to the beauty of creation. Lewis, who would look up into the night sky and upon spotting Venus, sigh and whisper, "Perelandra" (Green and Hooper, p. 171) - this Lewis had a tremendous ability to portray the mysterious power of beauty. Beauty itself, the beauty of nature and of people, one might say, testifies to and, what is more, persuades of the existence of a loving and just God as no argument can.

For example, in the first novel of the Space Trilogy, Out of the Silent Planet, his descriptions of the celestial heavens and of the planet Malacandra astound. On the spaceship Ransom discovers that his nightmare idea of space as dark, cold, and utterly empty, dead, is wholly wrong. The very word "Space" seems a "blasphemous" slander for the heavenly "ocean of radiance in which they swam” (p. 32). Life pours into his body and mind and he is continually filled with a new energy; he cannot feel fear, only "tranquillity" and deep "delight” (pp. 31-32). And once on the planet Ransom learns before anything else "that Malacandra was beautiful" (p. 42). Here water is not merely blue in certain light but truly blue (p. 43). The vegetation and landscape is like "a watercolour world” from a “child's paint-box” (p. 42). The mountains rush skyward and hang so lightly in the air that all earthly mountains ever after would seem to him dwarf-like (p. 53). And the beauty of the valley with the island Meldilorn, the home of the angelic ruler Oyarsa, takes his breath away (p. 105). The almost circular sapphire lake is bordered by a purple forest, and the pale red island is a 
place of beauty - “so classic, so virginal ... lying so still, so secret--as no man has ever seen” (p. 105).

Lewis's vision of Beauty includes the true beauty of people-an inner beauty of character that radiates through their whole being. He draws attention to it in That Hideous Strength in the ordinary country folk, "apple-faced men, and women with elastic-side boots and imitation fruit on their hats" (p. 48). He underscores it when the women of St. Anne's select banquet gowns for one another that reveal their true selves, at once both common and strangely goddess-like (pp. 360-62). He highlights it in The Great Divorce when the housewife Sarah Smith is revered by a vast host of spirits as "one of the great ones” (p. 118). The love, courtesy, and joy that exudes from her in her glorified state is such that the amazed narrator recalls "the unbearable beauty of her face" (p. 118).

With great detail and passion Lewis portrays the image of Divine Beauty in nature and in people. His "beauty-loving eye" (cf. Montgomery, p. 31) points to the plenitude of Creation — of life created by and for love.

\section{Love}

Lewis's language of Joy enables us to experience genuine love. Not the selfish grasping emotion and lust for control that masquerades as love, but the real thing. In his fiction we experience love in its various forms: affection, friendship, eros, and divine love. Affection thrives, for instance, in The Voyage of the "Dawn Treader" when Lucy takes the bold Mouse Reepicheep in her arms and caresses him, something she does for the first and last time as he leaves for Aslan's country (p. 207). Friendship love is vast in Lewis's stories and forms the basis of every community, communities which unite talking animals, humans, angels, and God Himself. In That Hideous Strength, for example, the community of St. Anne's consists of animals and people of all classes, including the skeptic Andrew McPhee, who does not believe in God but is nonetheless a welcomed member who chooses their fellowship. Unlike the totalitarian coercion of the N.I.C.E., in which members must conform to their progressive ideology or be killed, kind-hearted friendship characterizes the community of St. Anne's. And the third human love, Eros, its challenges and its splendours, is captured in both his children's and adult fiction. For example, the start of erotic love is portrayed in the children Shasta and Aravis in The Horse and his Boy. The development of marital love informs That Hideous Strength, in the struggles and healing of the young couple Jane and Mark Studdock, and in the seasoned love of Professor Cecil and Mrs. Margaret Dimble.

But Lewis's greatest achievement, surely, is his portrait of divine love which inspires all the others. In the most endearing, compelling ways, Lewis enables his reader to feel what God's love is like. This is most memorable in his 
portrait of the great lion Aslan, the king of Narnia, who will set all things right. The miracle of the Incarnation, when God became human flesh, is mediated through the lion Aslan who enters his created world and meets characters where they are, whether as traitors, like Edmund in The Lion, the Witch and the Wardrobe, in dragon-form, like Eustace in The Voyage of the "Dawn Treader," or weeping with fear over one's dying mother, like Digory in The Magician's Nephew. Aslan is the One who dies for the enslaved traitor, and overcomes death. He lives to set his people free. He brings about the justice that a dying, tyrannous world cannot give. His sorrow is greater than anyone's, and his joy is everlasting. Which reader can ever forget the ecstatic joy of Aslan's game of catch with Susan and Lucy after his resurrection in The Lion, the Witch and the Wardrobe? When "all three of them rol[1] over together in a happy laughing heap of fur and arms and legs" (p. 148)? Followed by "perhaps the most wonderful thing that happened [to the sisters] in Narnia" - their swift ride across the land on Aslan's "warm, golden back," his "mane flying ... in the wind" (p. 149)? Divine love in Lewis's fiction is experienced by the reader as tangibly real. And in the force of such love, terrible pride like Queen Orual's in Till We Have Faces melts at last. In the force of such love, human darkness can finally turn to gold (cf. Hilder, p. 147).

\section{Conclusion}

In conclusion, Lewis's legacy as a Christian communicator to contemporary culture is the language of Joy. Whether in the heat of apologetic argument, or in the sweet delight of imaginative fiction, Lewis speaks the persuasive language of a robust joy. His example is timeless: recover earlier ideas; use everyday language; and practice the habit of humility. And always speak Joy, Heavenly Joy. Then we may awaken Heavenly desire in the hearts and minds of others. Speak Joy and others may fall in love with Goodness. ${ }^{5}$ Such desire once awakened, if faithfully followed, as Lewis suggested, will reveal falsehood after falsehood until truth is discovered (Pilgrim's Regress, p. 205). I close with the words of Christopher Mitchell:

At a time when many had ceased to believe that Christianity was a plausible picture of reality, Lewis reasserted its intellectual vitality and integrity. In doing so, he also reasserted Christians' right to enter into the public arena against those who routinely denied them that place.

By a rare combination of theological reflection and poetic imagination, Lewis thus achieved [what Dorothy L. Sayers once said of G.K. Chesterton] the

\footnotetext{
${ }^{5}$ cf. Marion Lochhead on how writers like Lewis made the experience of goodness attractive to readers.
} 
equally rare distinction of making theology "attractive, exciting and an uproariously fascinating quest,” causing once again the dead leaves of Christian doctrine to dance.

(“Making Doctrine Dance” p. 23, 26).

Thus, the passionate intellectual and artist C.S. Lewis invites us to enter this dance of Joy.

\section{Works Cited}

Butterfield, Rosario. The Gospel Comes with a House Key. Wheaton: Crossway, 2018. Print.

Chiaramonte, Perry. "Christian Persecution Seen in More Locations Across the Globe, New Report Shows.” Fox News. Fox Corporation. Feb. 2 2017. Web. 15 Aug. 2018.

Coghill, Nevill. “The Approach to English.” Light on C.S. Lewis. Ed. Jocelyn Gibb. San Diego: Harcourt, Brace \& World, 1966. 51-66. Print.

Como, James T. "Introduction.” Remembering C.S .Lewis: Recollections of Those Who Knew Him. 1979. Ed. James T. Como. San Francisco: Ignatius, 2005: 3351.Print.

Danielson, Dennis. “Intellectual historian.” The Cambridge Companion to C.S. Lewis. Eds. Robert MacSwain and Michael Ward. Cambridge: Cambridge UP, 2010. 43-57. Web. 15 Aug. 2018.

Edwards, Bruce L. "Rehabilitating Reading: C.S. Lewis and Contemporary Critical Theory.” The Taste of the Pineapple: Essays on C.S. Lewis as Reader, Critic, and Imaginative Writer. Ed. Bruce L. Edwards. Bowling Green: Bowling Green State U Popular P, 1988. 28-36. Print.

Farrer, Austin. “The Christian Apologist,” Light on C.S. Lewis. Ed. Jocelyn Gibb. San Diego: Harcourt, Brace \& World, 1966. 23-43. Print.

- - -. "In His Image.” Remembering C.S. Lewis: Recollections of Those Who Knew Him, Ed. James T. Como. San Francisco: Ignatius, 2005. 383-6. Print.

Gilson, Tom. "Post-Christian No More: The Western World Has Its Own Gods Now." The Stream. N.p., Jul. 15 2017. Web. 15 Aug. 2018.

Green, Roger Lancelyn, and Walter Hooper. C.S. Lewis: A Biography. London: Harper Collins, 1974. Print.

Hilder, Monika B. Surprised by the Feminine: A Rereading of C.S. Lewis and Gender New York: Peter Lang, 2013. Print.

Lee, Morgan. "Pope: More Persecuted Christians Today Than Ever Before." The Christian Post. N.p., Jul. 1 2014. Web. 15 Aug. 2018.

Lewis, Cleve Staples. The Abolition of Man or Reflections on Education with special reference to the teaching of English in the upper forms of schools. New York Macmillan, 1975. Print. 
- - -. "The Apologist's Evening Prayer." Poems. Ed. Walter Hooper. London: GeoffreyBles, 1966. 129. Print.

- - -. "Before We Can Communicate." God in the Dock. Grand Rapids: Eerdmans 1970. 254-7. Print.

- - -. "Christianity and Culture." Christian Reflections. Ed. Walter Hooper. Grand Rapids: Eerdmans, 1975. 12-36. Print.

- - -. "Christianity and Literature." Christian Reflections. Ed. Walter Hooper. Grand Rapids, MI: Eerdmans, 1975. 1-11. Print.

- - -. The Collected Letters of C.S. Lewis, Volume I (Family Letters, 1905-1931); Volume II (Books, Broadcasts, and the War, 1931-1949); Volume III (Narnia Cambridge, and Joy, 1950-1963). Ed. Walter Hooper. New York: HarperCollins, 2004, 2004, 2007. Print.

- - - "The Funeral of a Great Myth.” Christian Reflections. Ed. Walter Hooper. Grand Rapids: Eerdmans, 1975. 82-93. Print.

- - - The Great Divorce. New York: HarperCollins, 2001. Print.

- - - That Hideous Strength: A Modern Fairy-Tale for Grown-Ups. New York: Scribner, 2003. Print.

- --. The Last Battle. Harmondsworth: Puffin, 1975. Print.

- - - Letters to Malcolm. London: Harcourt, 1992. Print.

- - - The Lion, the Witch and the Wardrobe. Harmondsworth: Puffin, 1975. Print.

- - - "Modern Theology and Biblical Criticism.” Christian Reflections. Ed. Walter Hooper. Grand Rapids: Eerdmans, 1975. 152-166. Print.

- - - "The Necessity of Chivalry." Present Concerns. Ed. Walter Hooper. Harcourt: Brace Jovanovich, 1986. 13-16. Print.

- - - "On the Reading of Old Books." God in the Dock: Essays on Theology and Ethics. Ed. Walter Hooper. Grand Rapids: Eerdmans, 1970. 200-7. Print.

- - - Out of the Silent Planet. London: Pan, 1974. Print.

- - -.The Pilgrim's Regress: An Allegorical Apology for Christianity, Reason and Romanticism. Grand Rapids, MI: Eerdmans, 1992. Print.

- - -. "Preface." George MacDonald: An Anthology. Ed. C.S. Lewis. London: Fount, 1983. 21-35. Print.

- - - Prince Caspian. Harmondsworth: Puffin, 1975. Print.

- - -. "Psycho-analysis and Literary Criticism," They Asked for a Paper. London: Geoffrey Bles, 1962. 120-138. Print.

- - . The Silver Chair. Harmondsworth: Puffin, 1975. Print.

- - -. "Sometimes Fairy Stories May Say Best What's to be Said." On Stories: And Other Essays on Literature. Ed. Walter Hooper. New York: Harcourt Brace Jovanovich, 1982. 45-8. Print.

- - - Surprised by Joy: The Shape of My Early Life. London: Collins, 1976. Print.

- - -. "Is Theology Poetry?” They Asked for a Paper. London: Geoffrey Bles, 1962. 150-165. Print.

- --. The Voyage of the "Dawn Treader." Puffin, 1975. Print.

- - - "The Weight of Glory." The Weight of Glory and other Addresses. Grand Rapids: Eerdmans, 1977. 1-15. Print.

Lewis, W. H. "Memoir of C.S. Lewis." Letters of C.S. Lewis. London: Geoffrey Bles, 1966. 1-26. Print. 
Lindvall, Terry. Surprised by Laughter: The Comic World of C.S. Lewis. Nashville:Nelson, 1996. Print.

Lochhead, Marion. Renaissance of Wonder in Children's Literature. Edinburgh: Canongate, 1977. Print.

MacDonald, George. The Princess and the Goblin. Puffin, 1976. Print.

McGrath, Alistair. "The Life and Impact of C.S. Lewis.” Regent College, Vancouver, BC. 5 Jun. 2013. Lecture.

- - -. Personal interview. 18 Sept. 2018.

Mitchell, Christopher W. "Bearing the Weight of Glory: The Cost of C.S. Lewis's Witness." The Pilgrim's Guide:C.S. Lewis and the Art of Witness. Ed. David Mills. Grand Rapids: Eerdmans, 1998. 3-14. Print.

- - -. "Making Doctrine Dance.” Christian History 88 (2005): 23-26. Print.

Mohler, Albert. "Criminalizing Christianity: Sweden's Hate Speech Law.” Christian Headlines. n. pag., N.D. Web. 15 Aug. 2018.

Montgomery, L.M. Anne of Green Gables. Seal Books, 1996. Print.

Sayers, Dorothy L. "The Dogma is the Drama.” The Whimsical Christian: 18 Essays by Dorothy L. Sayers. London: Macmillan, 1978. 23-8. Print.

- - - . "The Greatest Drama Ever Staged." The Whimsical Christian: 18 Essays by Dorothy L. Sayers. London: Macmillan, 1978. 11-16. Print.

Trube, Robert C. “The Dogma is the Drama.” Bob on Books. N.p., Apr. 7 2017. Web. 15 Aug. 2018.

Wain, John. "A Great Clerke.” Remembering C.S. Lewis: Recollections of Those Who Knew Him. Ed. James T. Como. San Francisco: Ignatius, 2005. 152-63. Print.

Wooding, Dan. "Modern Persecution.” Christianity.com. Salem Web Network, Apr. 28 2010. Web. 15 Aug. 2018.

Monika Hilder is Professor of English at Trinity Western University, cofounder and co-director of Inklings Institute of Canada, and has published a 3volume study of C.S. Lewis and gender, including Surprised by the Feminine: A Rereading of C.S. Lewis and Gender (2013). Website: https://monikahilder.com Email: Monika.Hilder@twu.ca 
